\title{
Feasibility Test of Fishing Variables on Increasing Fishermen's Income in Tomini Bay, Gorontalo Province
}

\author{
Lis M. Yapanto ${ }^{*}$, Nuddin Harahab $^{2}$, Sudarto $^{3}$, Abdul Hafidz Olii ${ }^{4}$ \\ * 1Postgraduate Student of the Faculty of Agricultural Sciences Brawijaya University \\ ${ }^{2}$ Faculty of Fisheries and Marine Brawijaya University in Malang, Indonesia \\ ${ }^{3}$ Faculty of Agricultural Sciences Brawijaya University in Malang, Indonesia \\ ${ }^{4}$ Faculty of Fisheries and Marine University State of Gorontalo, Indonesia
}

Correspondent author ${ }^{1}$ *lizrossler@ung.ac.id

\begin{abstract}
This study aims to assess the household diversification of coastal fishing on coastal communities' welfare in the District of Kabila Bone, since August 2019-November 2019, 184 respondents, with a survey method. The data collected are primary and secondary data was done by using observation, interview techniques, documentation techniques. The lives and livelihoods of coastal fishing communities are very vulnerable to climate change and the environment. Diversification of fishermen's income sources outside of fisheries can be an effective way to overcome environmental change's adverse effects. This study aims to analyze the effect of business diversification on welfare, environmental sustainability, and welfare on environmental sustainability. The data collected are primary and secondary data, which is done using observation, interview, and documentation techniques. The independent variable is selected according to considerations based on the empirical conditions of the coastal area, the researcher's ability and the availability of supporting theories and the characteristics of the research area. The independent or exogenous variables chosen are fishery business (X1), livestock business. Based on the model developed from the relevant theory, the endogenous variables are welfare (Y1) and environmental sustainability (Y2); the model is tested using the PLS-based Structure Equation Model (SEM). The researcher's ability and the availability of supporting theories, and the characteristics of the research area. The independent or exogenous variables chosen are fishery business (X1), livestock business. Based on the model developed from the relevant theory, the endogenous variables are welfare (Y1) and environmental sustainability (Y2); the model is tested using the PLS-based Structure Equation Model (SEM). The researcher's ability and the availability of supporting theories, and the characteristics of the research area. The independent or exogenous variables chosen are fishery business (X1), livestock business. Based on the model developed from the relevant theory, the endogenous variables are welfare (Y1) and environmental sustainability (Y2); the model is tested using the PLS-based Structure Equation Model (SEM).

The model developed from the relevant theory, then tested on a model using the Structural Equation Model (SEM) based on SMART PLUS. The results of the analysis of effort diversification models suggest that the utilization of environmental services does not affect coastal communities' welfare.
\end{abstract}

Keywords: coastal communities; diversification; SEM-PLS; welfare; environmental sustainability, variable, 


\section{Introduction}

The population in the coastal areas has a relatively low economic level, wherein in the western season, some fishermen do not go to sea, and most of them depend only on fish in the sea. By looking at the above, it is necessary to make efforts to develop a side livelihood apart from being fishermen, improving technology and human resources, and capital as one of the ways that must be prioritized. By developing a business diversification model to optimize coastal communities' empowerment, the community can improve their standard of living for the better. It is hoped that by increasing business diversification, the economic growth of the community will improve and guarantee economic growth that can be enjoyed fairly and proportionally by the people on the coast. Increasing the productivity of fishermen household fishing businesses through modern fishing gear is very important in helping increase fishermen households' production, especially for capture fisheries. The strategy of monitoring and imposing strict sanctions on fishing gear that is not environmentally friendly, changes in the trading system for selling catches through the auction process at TPI and developing marketing access, improving the quality of human resources (fishing communities) through guidance and training on modern and environmentally friendly fishing, guidance related to the impact of climate change on the marine environment, as well as the ease of applying for capital loans for the development of fishing business activities.

\section{Linearity Assumption Testing}

Evaluation of the partial least square analysis method, namely, it is necessary to test the basic assumption, namely linearity, to test that the relationship between the tested variables has a linear relationship. Testing the linearity of the variable relationship aims to test whether the form of influence between the independent variable and the dependent variable is linear or not.

The linear relationship that occurs can be interpreted that an increase or decrease consistently follows the increase or decrease in variation in the predictor criterion. The relationship pattern forms a straight line. A good model is a model where the influence between the two variables is linear. The method used in testing the linearity in this study is the curve estimation test (curve of fit). The effect of the two variables is linear if the significance value of the test is smaller than the alpha used, which is $5 \%$.

According to Garson (2010) states that the relationship between variables has fulfilled the linear assumption because $F$ Deviation from Linearity is in the insignificant range $(F=1.054$; $p>0.05)$. Additional information shows that the assumption of linearity is quite strong because $F$-Linearity is in a significant range $(F=5.116 ; p<0.05)$. This study's linearity relationship is 
only related to structural equation modelling. Namely, the relationship between latent variables in the structural model is linear. The data linearity test aims to see whether the model used is linear. The following is a table that presents the linearity test results for the variables used in table 1.

Table 1. Test Results of Linearity Assumptions

\begin{tabular}{|c|c|c|c|}
\hline Independent Variable & Dependent variable & Sig. & Ket. \\
\hline Fishing Business (X1) & Well-being (Y1) & 0.000 & Linear \\
\hline Fishing Business (X1) & $\begin{array}{l}\text { Environmental Sustainability } \\
\text { (Y2) }\end{array}$ & 0.000 & Linear \\
\hline Animal Husbandry (X2) & Well-being (Y1) & 0.009 & Linear \\
\hline Animal Husbandry (X2) & $\begin{array}{l}\text { Environmental Sustainability } \\
\text { (Y2) }\end{array}$ & 0.805 & Non-Linear \\
\hline $\begin{array}{l}\text { Environmental Service Business } \\
\text { (X3) }\end{array}$ & Well-being (Y1) & 0.624 & Non-Linear \\
\hline $\begin{array}{l}\text { Environmental Service Business } \\
\text { (X3) }\end{array}$ & $\begin{array}{l}\text { Environmental Sustainability } \\
\text { (Y2) }\end{array}$ & 0.000 & Linear \\
\hline Well-being (Y1) & $\begin{array}{l}\text { Environmental Sustainability } \\
\text { (Y2) }\end{array}$ & 0.000 & Linear \\
\hline
\end{tabular}

Source: processed data, 20

Based on the results of the linearity test, the relationship between variables presented in table 1 shows that the relationship between fishing business $(\mathrm{X} 1)$ on welfare $(\mathrm{Y} 1)$ and environmental sustainability (Y2) can be said to be linear because the significance level is less than $5 \%$ or 0.05 . The livestock business variable $(\mathrm{X} 2)$ has a linear relationship with the welfare variable (Y1), with a significance value of less than $5 \%$ or 0.05 . However, it does not have a linear relationship with the environmental sustainability variable (Y2) because the significance level is greater than $5 \%$ or 0.05 . Meanwhile, the environmental service business variable (X3) does not have a linear relationship with the welfare variable $(\mathrm{Y} 1)$ because the significance value is greater than $5 \%$ or 0.05 ; and the relationship with the environmental sustainability variable (Y2) is linear because the significance value is less than $5 \%$ or 0.05 . Furthermore, the welfare variable $(\mathrm{Y} 1)$ has a linear relationship with the environmental sustainability variable (Y2), where the significance level is less than $5 \%$ or 0.05 . The test results concluded that not all relationships between variables in the structural model were linear, so that the assumption of linearity in the PLS analysis method was fulfilled. Thus, proving that the data used to meet the linearity requirements can be analyzed further. The welfare variable (Y1) has a linear relationship with the environmental sustainability variable $(Y 2)$, where the significance level is less than $5 \%$ or 0.05 . The test results concluded that not all relationships between variables in the structural model were linear, so that the assumption of linearity in the PLS analysis method was fulfilled. Thus, proving that the data used to meet the linearity requirements can be analyzed further. The welfare variable $(\mathrm{Y} 1)$ has a linear relationship with the environmental 
sustainability variable (Y2), where the significance level is less than $5 \%$ or 0.05 . The test results concluded that not all relationships between variables in the structural model were linear, so that the assumption of linearity in the PLS analysis method was fulfilled. Thus, proving that the data used to meet the linearity requirements can be analyzed further.

\subsubsection{Test of the Validity and Reliability of the Research Constructions (Outer Model)}

In the PLS analysis, the basic Evaluation carried out evaluates the measurement model (outer model) to determine the validity and reliability of the indicators measuring latent variables. Testing the validity and reliability of indicators in this study refers to discriminant validity, convergent validity, and composite reliability.

\section{Convergent Validity}

The Evaluation of the latent variable measurement model with reflective indicators is analyzed by looking at each indicator's convergent validity.

Convergent validity testing on PLS can be seen from the size of each indicator's outer loading against its latent variable. According to Solimun (2010); Ghozali (2011), Outer loading values above 0.70 are highly recommended, but loading factor values from 0.50 to 0.60 can still be tolerated within a t-statistic value above 1.96 or $p$-value $<0.05$. The outer loading of an indicator with the highest value is the strongest or most important measure in reflecting the latent variable in question. Nilai outer loading interprets the contribution of each indicator used to its latent variable.

\section{a. Evaluation of Fishing Business Variable Measurement Model (X1)}

In this study, the measurement of fishing business variables is reflected through five indicators, namely: experience (X1.1), family role (X1.2), technology (X1.3), capital (X1.4), and market (X1.5). ). Evaluation of the outer model or measurement model can be seen from each fishing business variable indicator's outer loading value. The following shows the extreme loading value of the fishing business construct in Table 2 .

Table 2. Result of Outer Loading of Catching Business Construction (UPI).

\begin{tabular}{cccc} 
Indicator & $\begin{array}{c}\text { Outer } \\
\text { Loading }\end{array}$ & t-statistics & $\begin{array}{c}\text { t-table } \\
\alpha=5 \%\end{array}$ \\
\hline UPI1 <- UPI & 0.788039 & 5.493949 & 1,960 \\
UPI2 <- UPI & 0.688644 & 3.809672 & 1,960 \\
UPI3 <- UPI & 0.859145 & 3.075225 & 1,960 \\
UPI4 <- UPI & 0.740788 & 4.260522 & 1,960 \\
UPI5 <- UPI & 0.811289 & 3,428820 & 1,960 \\
\hline
\end{tabular}

Source: Data processed, 2019 


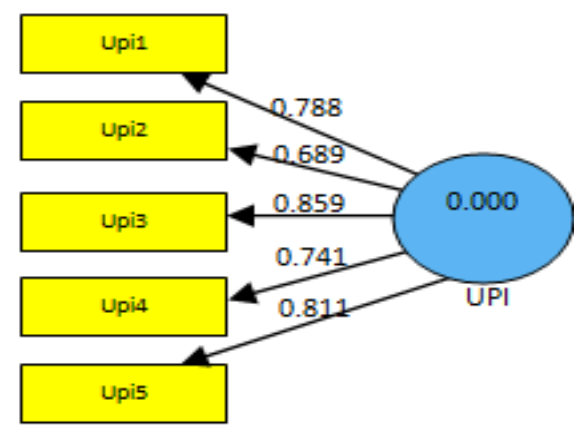

Figure 1.The results of the Outer Loading test for the fishing business variable (X1).

Source: processed data, 2019.

Table 2. describes the loading value of the fishing business variable factor (UPI), where the loading factor value on the upi 1 indicator, namely experience $(\mathrm{X} 1.1)$, is 0.788 , which is greater than the critical limit of 0.700 ; with a confidence level of $95 \%$ where, the t-statistical value of the experience indicator is greater than the t-table $(1,960)$. The loading factor value on the upi2 indicator, namely the family's role (X1.2) of 0.689 but still above the tolerant value of 0.6 with $95 \%$ confidence where the t-statistical value of innovative indicators is greater than the $t$ table (1,960). Upi3, upi4, and upi5 indicators, namely technology (X1.3), capital (X1.4) and market $(\mathrm{X} 1.5)$ respectively $0.859 ; 0.741$; and 0.811 is greater than 0.700 dan is also significant at the $95 \%$ confidence level where the t-statistic value of each indicator is greater than the ttable $(1,960)$. Thus the fishing business variable $(X 1)$ has been able to be well established or explained by the indicators of experience, the role of family, technology, capital, and the market or it can be said to be convergent valid on these indicators.

Based on the data analysis results, when viewed from the estimated value on the outer loading for each indicator, the indicator of the use of technology is the most important in reflecting the fishing business variables. The analysis results show that the highest loading factor is found at the upi3 indicator is a technical indicator of 0.859 . This indicator can explain the fishing business variable (X1) better than other indicators.

Furthermore, the market availability indicator's loading factor is 0.811 ; experience of 0.788 ; availability of capital of 0.741 ; and the smallest is the family role indicator of 0.689 . On the other hand, the $\mathrm{t}$-value shows that the indicator of experience is the strongest

used to measure the fishing business variable because the greatest value is obtained 5,4939 which is significant at the $95 \%$ confidence level $(1,960)$ compared to the indicators of capital, family role, market availability, and technology t-count values of 4.2605 each; 3,8097 ; 3,4288 and 3,0752.

DengaHowever, it can be concluded that the fishermen's experience in achieving business goals appear this is the most important indicator in reflecting fishing effort variables. 


\section{b. Evaluation of the Measurement Model of Animal Husbandry variables}

\begin{tabular}{|l|l|l|l|}
\hline Indicator & $\begin{array}{l}\text { Outer } \\
\text { Loading }\end{array}$ & t-statistics & $\begin{array}{l}\text { t-table } \\
\alpha=5 \%\end{array}$ \\
\hline UPT1 <- UPT & 0.901053 & 5.153765 & 1,960 \\
\hline UPT2 <- UPT & 0.683483 & 2.997548 & 1,960 \\
\hline UPT3 <- UPT & 0.961804 & 5.171301 & 1,960 \\
\hline UPT4 <- UPT & 0.948060 & 5.034131 & 1,960 \\
\hline UPT5 <- UPT & 0.949310 & 4.911276 & 1,960 \\
\hline
\end{tabular}

The measurement of livestock business variables is reflected through five indicators, namely: type of livestock (X2.1); the number of livestock (X2.2); technology (X2.3); capital (X2.4); and family roles (X2.5). The Evaluation of the outer model or measurement model can be seen from each indicator's outer loading value of the livestock business variable. The following is the outer loading value of the livestock business construct in Table 3 .

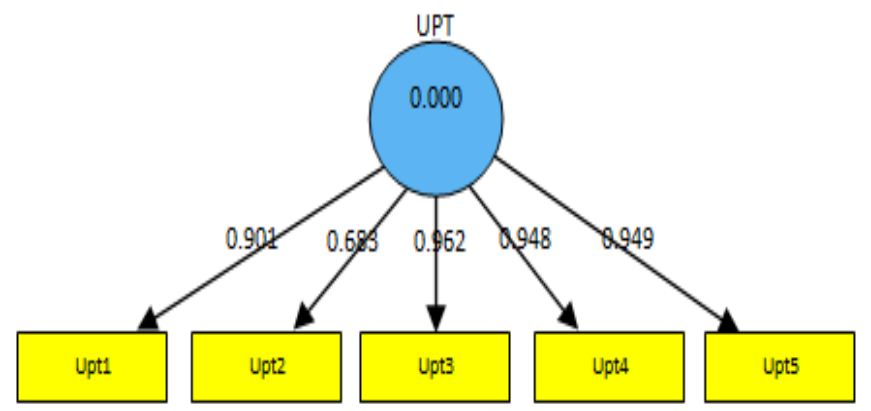

Figure 2.The results of the Outer Loading of Animal Husbandry Business variables (X2) Source: Data processed, 2019

Table 3 describes the factor loading value of the livestock business variable (UPT), where the factor loading value on the five indicators of the livestock business variable on average for each indicator is above 0.700 ; however, the upt2 indicator, namely the number of livestock (X2.2) is only 0.689 , which is less than the critical limit of 0.700 ; but it is still above the tolerant value of 0.6 with a confidence level of $95 \%$ where the t-statistical value of the number of livestock indicators is greater than the t-table $(1,960)$. UPT1 indicator; upt3; upt4; and upt5, namely the type of livestock (X2.1); technology (X2.3); capital (X2.4); and the role of family (X2.5) is also significant at the $95 \%$ confidence level where the t-statistic value of each indicator is greater than the t-table $(1,960)$. Thus the livestock business variable $(X 2)$ has been established or well explained by indicators of the type of livestock; livestock; technology; capital; and the family's role, or it can be said to be convergent valid on these indicators.

Based on the data analysis results, when viewed from the estimated value on each indicator's outer loading, the technical indicator is the most important in reflecting the livestock business variables. The analysis results show that the highest loading factor is in the upt3 indicator, namely the indicator of technology use at 0.962 , so that this indicator can explain the livestock 
business variable (X2) better than other indicators. Furthermore, the indicator's loading factor for the number of livestock is the lowest amounting to 0.689 , while the other indicators are in a value between 0.901 to 0.949 .

The t-value shows that the strongest technology indicator is used to measure the livestock business variable because the highest t-value is 5.1713 , which is significant at the $95 \%$ confidence level $(1,960)$ compared to the other four indicators with the $t$-count value between 2.9975 and 5.1537. Thus it can be concluded that, the use of technology, namely in terms of livestock maintenance, ease of obtaining feed sources and handling of livestock if the sick, have been properly implemented so that business owners can improve welfare and maintain environmental sustainability are the most important indicators in reflecting on livestock business variables.

\section{c. Evaluation of the Measurement Model of Environmental Service Business variables}

Measurement of environmental service business variables is reflected through five indicators, namely: type of material (X3.1), availability of raw materials (X3.2), regulations (X3.3), capital (X3.4), and the role of the family (X3.5). . Evaluation of the outer model or measurement model can be seen from the outer loading value of each environmental service business variable indicator. The following is the outer loading value of the environmental service business construct in Table 4.

Table 4. Result of Outer Loading Calculation for Environmental Service Business Constructs (UPL).

\begin{tabular}{llll}
\hline Indicator & $\begin{array}{l}\text { Outer } \\
\text { Loading }\end{array}$ & t-statistics & $\begin{array}{l}\text { t-table } \\
\alpha=5 \%\end{array}$ \\
\hline UJL1 <- UJL & 0.926732 & 46.357789 & 1,960 \\
UJL2 <- UJL & 0.935039 & 61.470012 & 1,960 \\
UJL3 <- UJL & 0.786435 & 17.334489 & 1,960 \\
UJL4 <- UJL & 0.921696 & 34.434470 & 1,960 \\
UJL5 <- UJL & 0.708268 & 15.350415 & 1,960 \\
\hline
\end{tabular}

Source: Data processed, 2019

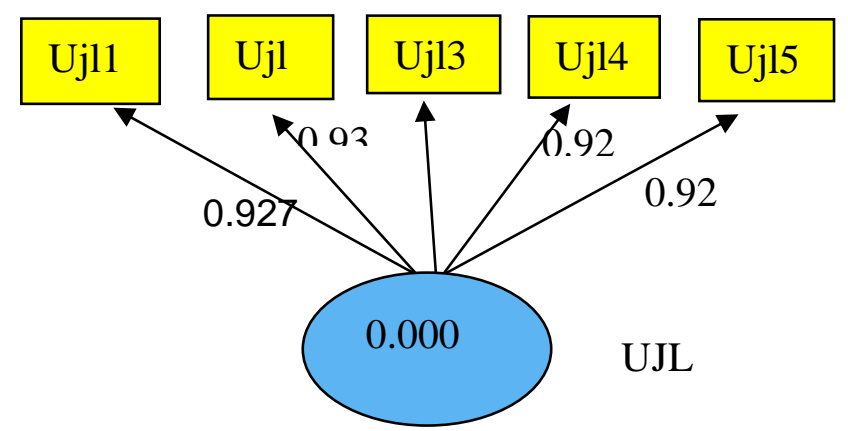

Figure 3. Results of Outer Loading Testing for Environmental Services Business variables (X3). Source: Data processed, 2019

Table 4 describes the loading value of the environmental service business variable (UJL), where the factor loading value on the test indicator 1 is the type of material of 0.9267 , the test 
indicator is the availability of raw materials of 0.935 ; the test indicator 3 , namely the regulation of 0.786 ; the test indicator 4 , namely the capital of 0.922 ; and the upl5 indicator, namely the role of the family of 0.708 , so that the average indicator value used is greater than 0.700 and significant at the $95 \%$ confidence level where the t-statistic value of each indicator is greater than the t-table (1.960). Thus the environmental service business variable (X3) has been able to be formed or well explained by indicators of the type of material, availability of raw materials, regulations, capital, and the family's role, or it can be said to be convergent valid on these indicators.

Based on the data analysis results, when viewed from the estimated value on the outer loading for each indicator, the indicator of raw material availability is the most important in reflecting the environmental service business variables. The analysis results show that the highest loading factor is found in the UPL2 indicator, namely the indicator of raw material availability

\begin{tabular}{llcc}
\hline Indicator & Outer & t-table \\
& Loading & & $\alpha=5 \%$ \\
& & & \\
\hline KSJ1 <- KSJ & 0.614584 & 4.962165 & 1,960 \\
KSJ2 <- KSJ & 0.646412 & 3.141292 & 1,960 \\
KSJ3 <- KSJ & 0.659272 & 4.891431 & 1,960 \\
KSJ4 <- KSJ & 0.874387 & 3.175848 & 1,960 \\
KSJ5 <- KSJ & 0.891404 & 3.323201 & 1,960 \\
KSJ6 <- KSJ & 0.865737 & 3.697818 & 1,960 \\
\hline
\end{tabular}

at 0.935 , so that this indicator can explain the environmental service business variable (X3) better than other indicators. Furthermore, the material type indicator's loading factor is 0.927 ; a capital indicator of 0.922 ; a regulatory indicator of 0.786 ; and the smallest is the family role indicator of 0.708 . Furthermore, the t-value, which can indicate the level of significance that the indicator of raw material availability remains the strongest, is used to measure environmental service variables because the greatest value is obtained, namely 61.47 , which is significant at the $95 \%$ confidence level $(1,960)$ compared to indicators of types of materials, regulations capital and family roles. Thus, the availability of raw materials as reflected by the availability of sufficient materials and having economic value is the most important indicator in reflecting the environmental service business variables.

\section{c. Evaluation of the Welfare Variable Measurement Model}

Measurement of the welfare variable is reflected through six indicators, namely: income (Y1.1), labour (Y1.2), education ( $\mathrm{Y} 1.3)$, home (Y1.4), home facilities (Y1.5), and health ( $\mathrm{Y}$ 1. .6). The outer model or measurement model's evaluation can be seen from each welfare variable indicator's outer loading value. The following shows the value of the outer loading of the welfare construct in Table 5.

Table 5. Results of the Outer Loading of Welfare Construction (KSJ).

Source: Data processed, 2019 


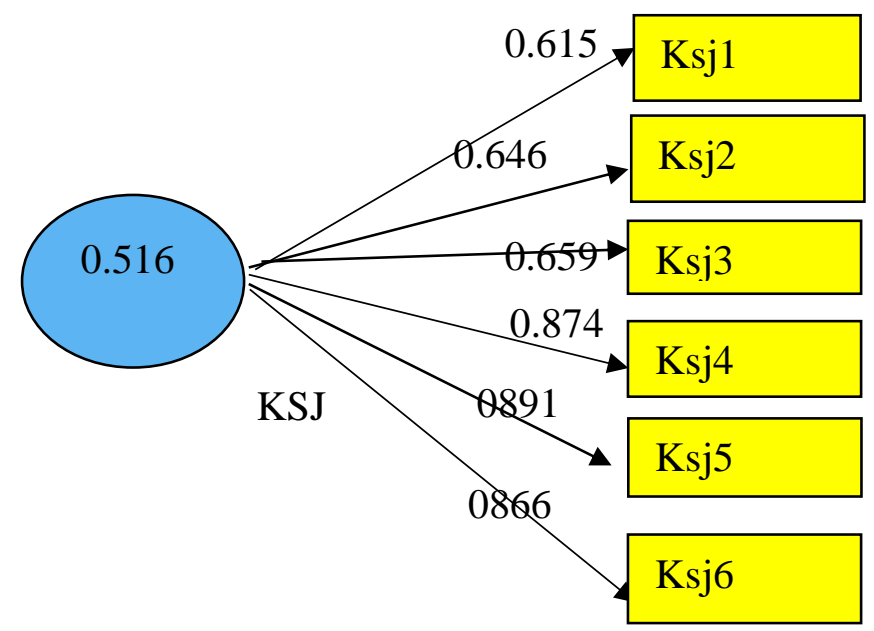

Picture 4. The Outer Loading Test Results for the Welfare variable.

Source: Data processed, 2019

Table 5. describes the factor loading value of the welfare variable (KSJ), where the factor loading value on the ksj1 indicator; ksj2; and ksj3, namely income, labour and education, respectively $0.615 ; 0.646 ; 0.659$, which is less than the critical limit of 0.700 ; but it is still above the tolerant value of 0.6 with a confidence level of $95 \%$ where the t-statistical value of income, labour and education indicators is greater than the t-table $(1,960)$. Furthermore, on the ksj4 indicator; ksj5; and ksj6, namely houses, housing and health facilities, the loading value of each factor was $0.874 ; 0.891 ; 0.866$, which is greater than the critical limit of 0.700 , with a confidence level of $95 \%$ where the t-statistical value of the indicators of houses, housing and health facilities is greater than the t-table $(1,960)$. Based on the data analysis results, when viewed from the estimated value on the outer loading for each indicator, the indicator of home facilities is the most important in reflecting the welfare variable. The analysis results show that the highest loading factor is found in the ksj5 indicator, namely the home facilities indicator at 0.8914 , so that this indicator can explain the welfare variable $(\mathrm{Y} 1)$ better than other indicators. Furthermore, the house indicator's loading factor is 0.874 ; the health indicator is 0.866 ; the education indicator is 0.6592 ; the clear job indicator is 0.6464 , and the smallest is the income indicator of 0.615 . On the other hand, the t-value, which shows the level of significance that the income indicator shows, is the strongest used to measure the welfare variable because the largest value is obtained, namely 4,962 , which is significant at the $95 \%$ confidence level $(1,960)$ compared to other indicators. Thus, it can be concluded that income, which is reflected in the profit earned from fishing, livestock farming and environmental service businesses, with an increase in sales volume, is the most important indicator in reflecting the welfare variable.

d. Evaluation of Measurement Model for Environmental Sustainability

\section{Variables}


Measurement of environmental sustainability variables are reflected in three indicators, namely: knowledge (Y2.1), attitude (Y2.2), and behaviour (Y2.3). Evaluation of the outer model or measurement model can be seen from the outer loading value of each indicator of the environmental sustainability variable. The following is the outer loading value of the environmental sustainability construct in Table 6.

Table 6. Calculation Results of Outer Loading Constructions for Environmental Sustainability $(\mathrm{KL})$.

\begin{tabular}{llll}
\hline Indicator & $\begin{array}{l}\text { Outer } \\
\text { Loading }\end{array}$ & t-statistics & $\begin{array}{l}\text { t-table } \\
\alpha=5 \%\end{array}$ \\
KL1 <- KL & 0.923878 & 8.466075 & 1,960 \\
KL2 <- KL & 0.647676 & 2.290008 & 1,960 \\
KL3 <- KL & 0.896433 & 6.451619 & 1,960 \\
\hline
\end{tabular}

Source: Data processed, 2019

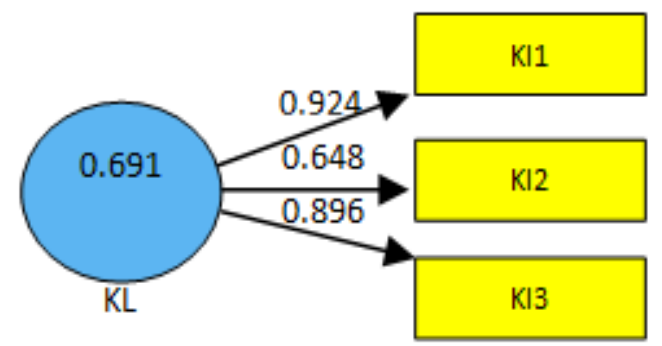

Figure 5.The Outer Loading Test Results for Environmental Sustainability (Y2)

Source: Data processed, 2019

Table 6 describes the value of the loading factor for the environmental sustainability variable $(\mathrm{KL})$, where the factor loading value on the indicator $\mathrm{KL} 1$; and $\mathrm{kl} 3$, namely knowledge and behaviour of 0.924 respectively; 0.896 , which is greater than the critical limit of 0.700 , with a $95 \%$ confidence level where the t-statistical value of knowledge and behaviour is greater than the t-table (1.960). Furthermore, the kl2 indicator, namely the loading factor value's attitude, is smaller than the critical limit of 0.700 . However, it is still above the tolerant value of 0.6 with a confidence level of $95 \%$, where the t-statistical value of the attitude indicator is greater than the $t$-table $(1,960)$. Thus the environmental sustainability variable $(Y 2)$ has been able to be 
well established or explained by indicators of knowledge, attitudes and behaviour or can be said to be convergent valid on these indicators. Based on the data analysis results, when viewed from the estimated value on the outer loading for each indicator, the indicator of knowledge is the most important in reflecting the environmental sustainability variable. The analysis results show that the highest loading factor is found in the Kl1 indicator, namely the knowledge indicator of 0.924 , so that this indicator can explain the environmental sustainability variable (Y2) better than other indicators. Furthermore, the behaviour indicator's loading factor is 0.896 , and the smallest is the attitude indicator of 0.648 .

Furthermore, the t-value indicates the significance level that the indicator of knowledge shows is the strongest used to measure environmental sustainability variables because the largest value is obtained, namely 8.466 , which is significant at the $95 \%$ confidence level $(1.960)$ compared to other indicators. Thus it can be concluded that, the knowledge that is reflected from the knowledge of marine and coastal resources, knowledge of coastal and coastal environmental conditions and knowledge of the benefits of protecting the coastal and coastal environment are the most important indicators in reflecting environmental sustainability variables.

\section{Conclusion}

1. The indicators used in the variable Capture Fisheries, Animal Husbandry, and Environmental Service Businesses are valid and appropriate to be used as indicators.

2. The more influential indicators are the technical indicator, the role of family and capital 


\section{References}

[1] Alberti, M. (2010). Maintaining Ecological Integrity And Sustaining Ecosystem Function In Urban areas. DOI:https://doi.org/10.1016/i.cossut. 2010.06.007

[2] Aryani, F. (1994) Analysis of Work and Revenue Contribution of Fishermen's Families in Economic Activities in Pantai Village: A Case Study in Desa Pasisir Baru Ke. Cisolok, Sukabumi Regency. IPB Bogor.

[3] Arifiani, NA, \& Mussadun, M. (2016). Study of Public Perceptions of the Sustainability Level of the Coastal Area of Sarang District. Journal of Regional and Environment, 4 (3).https://doi.org/10.14710/jwl.4.3.171-186

[4] AryonoB. (2004). Study Role Development Tourism Bahari Towards Fishermen's Welfare. Postgraduate Undip Semarang

[5] Ayob, AM (1979). Micro Economic Theory of the Kuala Lumpur Language and Literature Council.

[6] Regional Planning and Development Agency for Bone Bolango Regency. (2006) Preparation of the Master Plan for the Development of Marine and Land Fisheries in Gorontalo Province. Bappeda of Bolango Regency

[7] Brunbjerg, AK., Borchsenius, F., Eiserhardt. W, L et al., (2012a) Disturbance drives phylogenetic community structure in coastal dune vegetation. J Veg Sci23: 1082-94.

[8] Baharsyah, S. (1990). Business opportunities that remain wide in the agricultural sector Prisma No. 2 p. 86LP3S

[9] Bengen, DG (2000). Determination and Management of Protected Areas in Coastal, Marine and Small Islands. Workshop Papers. Directorate General of Coastal, Coastal and Small Islands. Ministry of Marine Affairs and Fisheries of the Republic of Indonesia. Jakarta.58 p.

[10] John, K., Fikret, B., Anthony, C., Evelyn, P., \& Melanie, W. (2007). The Role of Participatory Governance and Community-Based Management in Integrated Coastal and Ocean Management in Canada, Coastal Management, 35: 1, 79-104, DOI:10.1080 / 10.1080 / 08920750600970511

[11] Jager, W., Janssen, MA, De Vries, HJM, De Greef, J., Vlek, CAJ (2000) Behavior in Commons Dilemmas: Homo Economicus and Homo Psychologicus in an EcologicalEconomic Model. Ecological Economics 35, 357-379

[12] Johansson, PO, B. Kristrom and KG Maler. (1989). Welfare Evaluation in Contingent Valuation With Discrete response data: Comment, American Journal of Agricultural Economics 71: 10054-1056

[13] Jume'edi. (2005). The Role of Women in Increasing Fishermen's Family Income in Ujung Batu Village, Jepara District, Jepara Regency. Undip Semarang Postgraduate Program

[14] Katz, ML, and HS Rosen. (1994). Microeconomics Second Edition. Richard D Irwin, Inc. Kay, R. and J. Alder 1999 Coastal Planning and Management E.FN Sponge. London, UK and New York, USA

[15] Kesteven, GL. (1973). Manual of Fisheries Science: Part I An Introduction to Fisheries Science.FAO Fisheries Technical Paper 18: 231

[16] Knipscheer, HC, AJ De Boer., M Sabrani., TO Soedjana. (1987) The Economic Role of Goats and Lambs in Indonesia, a West Java Case Study in P.S. Hardjosworo, JM Levine (Editor) Livestock Development in Indonesia (Role System Model) Yayasan Obor Indonesia Jakarta Page 112-134

[17] Kaswadji, R. (2001). Ecosystem Linkages in Coastal Areas. IPB Bogor Coastal and Marine Ecosystem Analysis Materials

[18] Komariyah. (2004). Formulation of Traditional Marine Fisheries Product Processing Business in Pekalongan City. University Postgraduate Program 
[19] J., Kearney, F., Berkes, A., Charles, E., Pinkerton., \& M. Wiber. (2007). The role of participatory governance and community-based management in integrated coastal and ocean management in Canada. Coastal Management.https://doi.org/10.1080/10.1080/08920750600970511

[20] Kusnadi, MA (2002). Social Conflict of Fishermen, Poverty, and Struggle for Fishery Resources. Yogyakarta LkiS.

[21] Lee, F., Yok Shiu. (1994). Community-Based Urban Environmental Management Local NGOs as Catalys. Regional Development Dialogue. Autumn. Vol. 15. No.2

[22] Levina, JM (1987). Forming a Model of Animal Husbandry System in the Tropics with Special Reference to the Situation in Indonesia in P.S. Hardjosworo, JM Levina (editor) Animal Husbandry Development in Indonesia (System Model and Role) Yayasan Obor Indonesia, Jakarta

[23] Lopez, Y. (2005). Economic Development, Human Resources, Regional Infrastructure, Government Services and the Environment Towards a Self-reliant and Cultured Belu. Balitbangda Journal No 2 Year 01 April-June 2005

[24] Monintja, DR (1987). Several Technology Options for Utilizing Marine Biological Resources in Indonesia. PSP Department Bulletin Vol 1 No 1 Fac. IPB Fisheries. Bogor

[25] Maarten, Bavinck., Svein, Jentoft., Joeri Scholtens. (2018). Fisheries as social struggle: A new social science research agenda, Marine Policy. Volume 94, Pages 46-52, ISSN 0308-597X, HTTP: //doi.org/10.1016/j.marpol.2018.04.026.

[26] Murray, A ,. Rudd, M., Dickey-C., Johanna, F., Ellen, J., Nicol, M.,

[27] Macdonald., Richard, M., Margaret, R., Torsten, T., Jason, S.Link. (2018). Ocean Ecosystem-Based Management Mandates and Implementation in the North Atlantic. Frontiers in Marine Science 5.

[28] Monintja, DR (2001). Training for Trainers for Integrated Coastal Management Proceedings of the Bogor Coastal and Ocean Resources Study Center. Bogor Agricultural University $156 p$

[29] Suparmoko M., Ratnaningsih M., Setyarko Y., Widyantara, G. 2005. Economic Evaluation of Marine and Coastal Natural Resources of Kangean Island, Natural Resources Accounting, Edition 2005/2006 First Edition. January 2005, BPFE, Yogyakarta

[30] Suparmoko, M., Ratnaningsih, M., Setyarko, Y., Widyantara, G. (2005) Economic Evaluation of Natural Resources in Sikka Regency, Proceeding of Natural Resources and Environmental Accounting. Book 2 First Edition First Edition. April 2004. Ed. Ratnaningsih M., et. Al. BPFE, Yogyakarta

[31] Supriharyono. (2005). Rehabilitation and Conservation of Resources in Coastal Areas, Undip MSDP Doctoral Program. Not published

[32] Suradisastra, K. (1980). Some Variables in Goat Farming in Central Java, Animal Husbandry Research Institute Sheet 10 (2): 16-19

[33] Tangke, U. (2010). Analysis of the potential and level of exploitation of pompano fish (Carangidae sp) resources in the Flores Sea, South Sulawesi Province. Agrikan: Scientific Journal of Agribusiness and Fisheries, 3 (2). https://doi.org/10.29239/j.agrikan.3.2.31-38

[34] Yapanto, L. M \& Modjo, ML (2018). Assessing public awareness level on the preservation of coral reefs (The case study in Biak Numfor, Papua, Indonesia). Ecology, Environment and Conservation, 24 (4)

[35] Yapanto, L. M., Salam, A., \& Hamzah, Z. Y. (2020). TATANIAGA DAN MARGIN PEMASARAN IKAN TUNA DI KOTA GORONTALO ( The marketing of Tuna Fish in Gorontalo City ) mengetahui efisiensi pemasaran ikan metode survei, menurut Singaribuan menggunakan metode purposive. 2(2), 38-45. 